\section{Baudrillando: o lado mais obscuro da globalização}

\section{RESUMO}

Do mundo bipolarizado passou-se para o mundo globalizado, após a queda do Muro de Berlim, em 1989.0s conceitos de pós-orgia e simulacro, de Jean Baudrillard, dão sustentação à interpretação da nova ordem capitalista, entrelaçados com as concepções de pósmodernidade e pós-história. As questões centram-se nos fenômenos extremos da dessimbolização, da clonagem e do panopticismo, como apanágios pós-orgíacos. Em meio a essa efervescência, levanta-se 0 questionamento sobre os países terceiro-mundistas: realizaram-se as utopias?

\section{ABSTRACT \\ We passed from a bipolarized world to a globalized one after the fall of the Berlin Wall, in 1989. Jean Braudrillard's concepts of post-orgy and simulacrum give supoort to the interpretation of the new capitalist order, intertwined with the concepts of post-modernity and post-his- tory. The issues focus on the extreme phenomena of "dessimboliza- tion", cloning, and pan-opticism, as a post-orgiastic appanage. In the middle of this efervescence, a question is raised concerning the Third World countries: were the utopias accomplished?}

\section{PALAVRAS-CHAVE}

- Filosofia política (Political philosophy)

- Globalização (Globalization)

- Pós-modernismo (Postmodernism)

\section{Introdução}

O presente trabalho tem por finalidade retomar algumas especificidades em que se constituiu a globalização, nos contornos de uma póshistória, a partir da segunda metade do século XX. Tal deflexão - porque se entendem, esses conceitos, como uma espécie de desvio ideológico verticalizados que se impõem como crenças nesse novo estágio do capitalismo - tem como principal aporte o livro A Transparência do Mal: ensaios sobre fenômenos extremos, de Jean Baudrillard (1992). Nele, o autor propõe um conjunto teórico ao mesmo tempo intrigante e mordaz, que não poupa as sociedades advindas do que se convencionou chamar de modernidade, identificando-a como o momento da "orgia".

Esse termo, aliás, inteiramente pertinente, na medida em que representa todas as formas de conquistas alcançadas pelo ser humano, e o seu momento subseqüente, a "pós-orgia". A alusão orgíaca simboliza o estado de êxtase em que as sociedades, principalmente as mais desenvolvidas, ficaram, ao perceberemse não só produtoras de coisas que passaram a ser determinantes para suas atividades econômicas e políticas, sob a ilusão de um eterno estado de progresso e lazer em todos os campos e patamares da economia e da cultura, mas também num novo estágio de liberdades, tanto individuais quanto coletivas. Porém, como toda orgia em determinado momento acaba e, quando isso acontece, cai-se no torpor da "pós-orgia", a sensibilidade, a motilidade ${ }^{1}$, enfim, todas as atividades reduzem-se de tal forma que não se tem mais exatamente a consciência do que se passa ao redor. Neste estado, resta o simulacro, ou seja, a busca da satisfação, não mais pela consecução funcional do indivíduo, mas pela hiperexacerbação do simbólico.

Ao reportar-se a Andy Warhol, no seu desejo: "Eu quero ser uma máquina", e apoiando-se na definição de Gombrowicz², Baudrillard busca interpretar a "afetação", afirmando:

E é esse estado de alma insólito em que se toma consciência do artifício do próprio estado e que consiste em criar-se uma espécie de duplo artificial, em entrar na
Rosane Maria Rizzi Cattani Doutora em Antropologia pela Universidade de Buenos Aires 
sombra artificial de seu duplo, em produzir o autômato artificial de sua própria essência e, por isso, em exteriorizar-se como outro, pela graça dos signos.

Para Baudrillard, a afetação, coincidente ao estágio do valor-signo, passa pela percepção de que, na proposta de Warhol, há como que uma frustração da maquinação, pois "onde a máquina comum produz o objeto, Warhol produz a finalidade secreta do objeto que é a de ser reproduzido". Essa reprodução só pode se dar "no 'nonsense' secreto que emana do processo mesmo da objetalidade", possível apenas numa espécie plural de si mesmo, onde a originalidade é apenas um mero artifício para a reprodutibilidade invariante.

Essa é a pertinência do desejo perseguido por Warhol, trazido por Baudrillard como exemplo de "pós-orgia", pois, neste estádio, sucessivamente, vai-se ter no lugar da alma (que é singular) a máquina, no lugar do significado, o artifício, e assim por diante, até chegar no limite máximo da afetação, no simulacro do próprio ser humano pela clonagem. Dos fenômenos, este é o mais extremo: o desejo secreto do "ser" reproduzir-se, perpetuando-se na sua própria objetalidade, "o último estádio da história da modelação do corpo, aquele em que, reduzido a sua fórmula abstrata e genética, o indivíduo é fadado a demultiplicação serial". Referenciando Walter Benjamin sobre a obra de arte na era da reprodutibilidade técnica, Baudrillard reafirma que o que se perde "na obra serialmente reproduzida é sua aura, essa qualidade singular do aqui e agora, sua forma estética (...) o que está perdido é o original...". O clone humano é o kitsch, o artífice da possibilidade de refazer e refazer-se, a partir da criação original, ad instar dominum. Eis aqui o espectro ${ }^{3}$ da clonagem, ideal morbífico de quem se pensa irrefragável e impõe prepotência. Contudo, para Baudrillard, de certa forma, Warhol não deixa de aproximarse de uma espécie de estado da graça, quando "chega a encantação da máquina, através da reprodução da exatidão banal do mundo, cada vez menos sujeito de desejo, cada vez mais próximo do nada do objeto".

Nesta mesma perspectiva, o conceito de "dessimbolização", em Canevacci (1990, p. 133), procura explicar essa proliferação do signo que termina por tomar o espaço da concretização e até do ser, porque propõe "uma prepotente pressão social [que] quer unir 'logo' o símbolo à coisa, o sinal alusivo ao ato consumado; quer dessimbolizar". O conceito de dessimbolização encontra-se exatamente na medida em que o objeto singular perde sua significação original como se fosse dissociado de sua anima - para dar lugar a uma imagem, por vezes até grotesca, porque apenas induz ao referente e de forma fechada, não se tratando de uma "obra aberta", para lembrar Eco (1971). Ao contrário, impõe a rigidez. A emocionalidade do devir se volta para um agora que se traduz não na temporalidade, mas no exagero do desejo travestido em ato de aparência. As relações mudam e se tornam estanques.

Contra a ordem da formalidade racional, que sempre é do positivo (que já é uma simulação), não mais se põe uma contradição estabelecida na relação real do sujeito/sujeito, mas numa outra ordem onde a superfície tensional se dá entre objeto/objeto, que é a simulação do simulacro. Para Baudrillard, este "é o lugar da metástase, do encadeamento maquímico de todos os seus processos de uma programação infinita sem organização simbólica, sem objetivo transcendente, na pura promiscuidade consigo mesmo", significando, ainda, segundo o autor, que "há uma grande afetação em simular ser um homem, em não ser si mesmo". O próprio Canevacci faz emergir essa promiscuidade simulada no frenético jogo dos videoclipes, nas "guitarras fálicas", como expressões dessa simbólica, sem nenhum objetivo transcendente senão o de exacerbar as percepções na repetição, induzindo ao que Baudrillard conceituou de estado fractal.

O estado fractal significa que, na realidade, nada muda, apenas passa a ocorrer uma libertação dos conceitos sobre as coisas e suas essencialidades, levando a uma perda referencial. Essa anulação das referências é a possibilidade da autoreprodução tendente ao infinito que, noabsoluto rigor, indicaa permanente funcionalidade do objeto. Nas palavras do filósofo, "as coisas continuam a funcionar ao passo que a idéia delas já desapareceu há muito. Continuam a funcionar numa indiferença total a seu próprio conteúdo. E o paradoxo é que elas funcionam melhor ainda". Já em Warhol, esse espectro se apresenta em simulações de ídolos das artes cinematográficas, cujas dimensões agigantadas expõem a objetalidade de seus seres, exatamente na significação mais peculiar de suas iconicidades: a sedução. É nessa compleição que se entende a sensibilidade com 
a qual ele conseguiu captar o sinal dos tempos e, possivelmente, tenha sido o precursor da dessimbolização ${ }^{4}$. Para a Ciência, tocou o papel primordial de transcender a linguagem humana na sua réplica mais perfeita, o signo dos signos, a célula-tronco, a apoteose do simulacro. Por isso, para Baudrillard,

nada mais (nem mesmo Deus) desaparece pelo fim ou pela morte, mas por proliferação, contaminação, saturação e transparência, exaustão e exterminação, por epidemia de simulação, transferência na existência segunda da simulação. Já não há modo fatal de desaparecimento, mas sim, um modo fractal de dispersão.

A linguagem revela elementos que, quando desconstruídos, aparecem como uma armadilha do inconsciente contra a tentativa de racionalizar certas convenções ou crenças sedimentadas no imaginário coletivo pela cultura. Isto é, não se pode passar ileso sem a referência do autor ao Ente superior, pois, mais do que anunciar a não-morte de Deus, fica implícita, aí, a sua presença, ainda que desaparecida pela desfaçatez dos mega shows, os quais só reafirmam essa idéia de proliferação imagética, condição precípua da simulação. Contudo, não há como simplesmente refutar a possibilidade de Sua existência, sobretudo e principalmente na crítica à clonagem como uma tentativa de retirar da coisa a sua essencialidade que, no humano, não se coaduna somente com a sua forma, mas com a sua existência concreta, no inexplicável, do qual emana muito mais que uma materialidade passível de ser reproduzida. A partir disso, pode se compreender ainda mais o significado do ideal-clone, pois ele aparece não mais como a imagem e semelhança de Deus, mas como imagem e semelhança da classe social que se quer eternizada, retirando não a sua essencialidade, mas o seu conceito construído na tese, na alteridade dura, de onde resulta a possibilidade uma perigosa antítese. Nesse caso, pode-se extrapolar, afirmando que essa idéia, talvez sempre presente no desejo humano de ser o próprio Deus, foi privatizada, na medida em que somente o poder econômico tem acesso à reprodução de si mesmo, não mais pelas vias naturais, mas pelo controle absoluto da informação, da tecnologia e do conhecimento. Esse é o principal vórtice que movimenta o avanço da globalização, cujo conceito explicita-se, cada vez mais, quando se pensa o desejo da proliferação ad extremum, que é o ápice da dominação. E se não existisse, ainda, um resquício de impedimento moral ${ }^{5}$, a questão política jamais seria, por si, uma força tão potente à crítica, que impediria, de fato, a concretização dessa vontade, embora o novo deus não se entregue à possibilidade da própria morte, porque não acredita no perecimento de suas ações que, a rigor, como tudo, têm sua reversibilidade. (No final das contas o Verdadeiro sempre tem uma carta na manga). Daí a pertinência da afirmação de Orwell (1948): "sempre haverá a intoxicação do poder, sempre aumentando e sempre crescendo sutilmente".

O processo do simulacro, da dessimbolização, da clonagem, passa a ser, também, o substitutivo à construção dos espaços revolucionários, na medida em que as figuras rígidas do Estado, da burguesia, da repressão ostensiva, da censura dissimulada, bem como das relações sociais foram abstraídas da sua originalidade para serem demultiplicadas ${ }^{6}$ em redes: tudo é permissível, tudo se desmancha no ar para se reconstruir no seu "duplo artificial", no "autômato artificial de sua própria essência", no signo, na possibilidade da reprodução da mesmice ao infinito e com muito mais força. Nesse processo, o ato real não é mais tão importante; o ato simbólico recoloca o ser histórico na dimensão da irrealidade, porém recomposto pela força evocativa de uma reconciliação superficial, como se essa fosse, agora, o ato verdadeiro quando, na realidade, é o substitutivo do vazio interposto. Esta é a "pós-orgia", a recolocação de todas as expressões e desejos do humano (sexualidade, por exemplo) num outro patamar, numa espécie de reconfiguração do espaço do 'Big Brother', onde, neste "instante" ${ }^{8 "}$ todos são, ao mesmo tempo, objetos e sujeitos do próprio voyeurismo, o que pode ser sempre entendido como um reducionismo das potencialidades sociais. Por todas essas questões e muito mais, é que se entende que, no espaço da "pós-orgia", no simulacro da expansão de todos os domínios, ou estádio fractal, encontra-se o terreno fértil para a globalização. Para alguns, a explosão das forças constituídas é exaltada como um novo estágio do progresso, acrescido do suspiro de alívio pela noção de impossibilidade da transformação sistêmica. Para outros, é apenas o eco de alguma coisa que foi, mas que, ao mesmo tempo, ainda está presente, não superada, e 
que só se mantém pela repetição extensiva, constituindo-se na 'nova ordem' de dominação. Como substrato a interpretações, ambas as posturas contêm em si o mesmo gene que corrobora as permanentes diferenças sociais instituídas desde os primórdios do capitalismo, no que pese à noção da Pós-história.

Embora não usando as terminologias já consagradas - globalização e pósmodernidade -, até porque não se considera nenhum arauto dessas conceitualidades(sic), Baudrillard deixa claro que as utopias já se realizaram, a revolução já aconteceu, embora "não do modo como esperávamos". De fato, para os convivas que se locupletaram da "orgia" o fim da Guerra Fria representa a dimensão positiva da universalização do capital. Porém, o capitalismo é e sempre será sinônimo de diferenças socioeconômicas, ainda que os subterfúgios, principalmente os de recursos mediáticos a viabilidade do estado fractal - mantenham esmaecida essa realidade. Certo ou errado, a ideologia continua muito bem sedimentada na divisão maniqueísta do mundo entre o bem e o $\mathrm{mal}^{9}$ e se repete, infinitamente, nas ações concretas, inclusive naqueles que não fazem parte ou não fizeram parte dessa explosão de 'liberdades' e 'progressos', mas ao contrário, foram e continuam a ser o seu subjectus. Nesse contexto, o simulacro torna-se o aporte da apatia política. É nesse sentido que, por Baudrillard, através da sua Transparência do mal, tentarse-á conduzir à própria constatação.

\section{Globalização, pós-modernidade, pós-história}

Osacontecimentos do séculoXXencaminharamse para uma conseqüência inversa daquela esperada pelas posturas revolucionárias de esquerda, porque não foi o proletariado que se internacionalizou, como era previsto pela teoria marxista, mas, sim, o próprio capitalismo. Para Octávio lanni (1998, p. 11), acontecimentos como a Primeira Guerra Mundial (1947-18), a Grande Depressão Econômica Mundial (1929) e a Segunda Guerra Mundial (1939-45) são exemplos explícitos das características da sociedade mundial 9 . No entanto, com a deflagração da Guerra Fria, a partir do discurso de Wisnton Churchill, em Fulton, nos EUA, em 1946, ocorre um novo impulso nesse processo, com a divisão do mundo em dois blocos reconhecidamente antagônicos: o Capitalismo, de um lado, e o Comunismo, de outro, tendo como foco principal de disputa, no final das contas, o mesmo objetivo: a hegemonia do poder mundial, da qual o capitalismo saiu vencedor.

Nessavisãodeblocos,poucosepercebeudo verdadeiro universo constituído nas diversidades, na medida em que outras realidades sempre estiveram postas, porém mantendo-se como estruturas invisíveis, porque subjugadas pelo jogo dicotômico e dominador. lanni (1998, p. 156) chega a afirmar que as dicotomias, "em larga medida, são realidades e metáforas produzidas pela prática e o pensamento europeu e norteamericano, católico e protestante, mercantil e pragmático, de modo a reconhecer, classificar, delimitar, codificar, destacar, privilegiar, marcar, estigmatizar". Pode-se reconhecer, nessas palavras, o universo ideológico como recurso à diferenciação tão necessária para a manutenção das tensões, exatamente na bipolaridade, enquanto assim interessava para os dois lados.

No entanto, o universo, fragmentado em desigualdades e contradições, nunca deixou de existir: era preciso ir buscar as verdadeiras diversidades, inclusive culturais, as quais sempre foram o sustentáculo da própria realidade, bem mais complexa que o sentido periférico dado à enfadonha, porém cruel, divergência (e que ainda se reproduz sobre outros focos). As chamadas esquerdas, principalmente não atreladas à União Soviética, passaram a ter papel preponderante nessa investida, cujo intuito ainda vislumbrava a luta de classes. As Ciências avançaram sob o paradigma materialista dialético, e o exercício da crítica difundiu-se, mas o socialismo não se internacionalizou. O capitalismo conseguiu dobrar o bloco soviético e o Muro de Berlim, literalmente, caiu em 1989 (data pontual). No que pese a importância do fim do Muro de Berlim, a grande transformação ocorrida a partir desse momento, primeiramente, deu-se no patamar da visão de mundo bipolarizado para o de mundo globalizado.

A aparente impossibilidade do avanço de um socialismo, nos mesmos termos, afirma lanni (1998, p. 147), se dá pelo "desenvolvimento extensivo e intensivo do capitalismo [que] continua a alcançar, absorver e reabsorver os mais diversos espaços, modos de vida e trabalho, culturas. A reprodução do capital, em escala, continua a ocupar e reocupar o mundo...". Segundamente, essa sensação de impossibilidade acabou por inibir as perspectivas utópicas, quebrando, em parte, a tenacidade dos movimentos de esquerda na 
organização internacionalista do proletariado, no mundo todo. Cuba, ironicamente para a América Latina, continuou isolada. Isso abre uma brecha para reafirmar o continuismo como se fosse um dado novo. Se bem se percebe, na ironia da globalização, a indistinção das coisas e das relações sociais constitui-se em fenômeno tanto do desencanto (e este acomoda), quanto da refuncionalização das redes, que "funcionam ainda melhor".

Em virtude dessa eficácia, os modelos, os códigos, as estruturas já não servem como referenciais, e aquilo que deveria ser o "poder do intelectual" - a crítica, a exposição aguçada da contradição - que revela a fragilidade desse monocordismo(sic) que é a asfixia imposta, acaba capturado pela mesma armadilha da auto-reprodução, então "grau Xérox da cultura". É daí, também, que se reproduz o desencanto da utopia "realizada", ou a "surpresa" do futuro que passou. O significado é, principalmente, político-econômico, na medida em que a dicotomia capitalismo/comunismo tornase subjugada pelo caráter universalizado do capital. Daí a alcunha de 'sem pátria', cujo apanágio vai ser a tecnologia, através da qual se desenvolve a capacidade, cada vez mais sofisticada, de canalizar as pulsões divergentes, dando a impressão, por um lado, de que a homogeneização do social atingiu seu sucesso e, por outro, conforme Valéry (1974, p. 48), de que "a máquina governa; a vida humana é rigorosamente controlada por ela".

Essa é, na realidade, a mais profunda expressão do fetiche, o auge da fragmentação do indivíduo, condição sine qua non para a alienação, em escala mundial, que, para Baudrillard, foi substituída por esta condição de "pós-orgia", cujo recurso mágico é o poder do símbolo sobre o sujeito, e sem contraposto. No seu momento marxista (1970) mais explícito, esse autor coloca os shoppings centers como os verdadeiros templos do devir - tudo ali se reproduz numa espécie de dispersão aleatória - onde a mercadoria substitui o sentido do ser pela própria coisa.

Os shopping centers estão cada vez mais sacramentados, principalmente se se tomar por base a afirmativa de LeBon ${ }^{10}$ que "uma pessoa não é só religiosa quando adora uma divindade, mas quando coloca todos os recursos da sua mente, a completa submissão da sua vontade e o profundo ardor do fanatismo a serviço de uma causa ou de um indivíduo que se torna o alvo e o guia de seus pensamentos e ações". Eis o sentido dos shopping: essa projeção dos indivíduos na tentativa de buscar respostas ao vazio que a história pós-orgíaca impôs no lugar da consciência: uma função sagrada que, além de atender às necessidades de segurança, próprias da condição da sociedade urbanizada atual, também se estabelece como o "lugar do gozo', do direito de ser feliz, o lugar do simulacro por excelência.

Ao se tomar a "orgia" como a condição da modernidade, esse entendimento passa pela noção psicanalítica de que, a partir da Revolução Francesa, há uma nova forma de percepção do ser. Trata-se de uma visão mais concreta, em que cada um tem o direito de realizar-se, de gozar a vida, imediatizando o sentido de realização que, anteriormente, era da dimensão da "outra vida". Antes, a morte que negava a vida, em vida, prometia recompensas alhures. Esse sentido realizava-se nos apelos emocionais de cunho religioso (ou de censura medieval) voltados para uma certa fatalidade que norteava o devir misterioso, gerando expectativas de realizações. Depois, no que pese a continuidade da religiosidade, pela experiência revolucionária que capacitou outra classe social a assumir o rumo da própria história, as promessas de recompensas tornaram-se mais tangíveis e foram normatizadas na Declaração dos Direitos do Homem e do Cidadão, de 1793, cujo Art.10 promete que "a meta da Sociedade é a felicidade comum". De certa forma, essa máxima passa a ser, também, a marxista, contendo promessas de transformações.

No entanto, a obscuridade produzida pela evolução histórica, a qual, para Baudrillard, vai corresponder ao estágio fractal ou pós-orgíaco, instaura um estado de hiperexacerbação de simulações. Antes, as possibilidades de transformações reais se davam pelas ações concretas dos sujeitos sociais conscientes, agora se dão pelos reinos de deuses mediaticamente (sic) construídos, pela possibilidade da felicidade vir de dentro de um "baú", pela exposição escatológica do próprio corpo, num reality show, ou pelas realizações oníricas num shopping Center.

Muito mais exemplos seriam passíveis de ser expostos aqui como base para esse momento histórico de fenômenos extremos, mas estes já são suficientes para criar a imagem do que para Baudrillard se apresenta como 
"uma compulsão centrípeta, como uma excentricidade de todos os sistemas, uma metástase interna, uma autovirulência febril que os leva a explodir além de seus próprios limites, a ultrapassar a própria lógica, não na pura tautologia, mas num aumento de força, numa potencialização fantástica em que eles arriscam a própria perda".

A questão em Baudrillard situa-se no que ele considera a "epidemia do valor de troca". A "pós-orgia" como sentido de valor-signo passa pelo "intento de classificação" do valor a partir de três momentos da sua evolução: "Um estádio natural do valor de uso, um estádio mercantil do valor de troca, um estádio estrutural do valorsigno. (...). Uma lei natural, uma lei mercantil e uma lei estrutural do valor", respectivamente. A evolutiva se dá numa certa correspondência entre o primeiro estádio, com o uso natural do mundo; o segundo, onde o valor se sujeita à lógica da mercadoria; o terceiro, corresponderia a um código, a um referencial estrutural de modelos.

Mas a magia teórica de Baudrillard (ou sua maldição) se dá na capacidade de reinventar o "viral" numa ordem que já nasceu fadada à autoproliferação: o quarto estádio, o fractal, "como os físicos que inventam a cada mês uma nova partícula vou aqui acrescentar uma nova partícula, a microfísica dos simulacros (...), o quarto estádio, estádio fractal, ou estádio viral, ou ainda, estádio irradiador de valor". Considerando tais distinções apenas como formalidades, ele reivindica, assim, sua posição dialética onde essa quatrilogia (sic) não se dá por exclusão, mas por sucessão e adicionamento mútuo, "numa trajetória hipotética", que corresponde às transformações que se sucedem na história das relações de trocas, sendo, então, o quarto estádio apenas a intensificação do terceiro, o valor-signo. Assim, consegue ultrapassar a mais básica das leis da física, o princípio tridimensional e, sem ser metafísico, coloca numa transordem a concretização da quarta dimensão (o que explicita, ainda mais, o simulacro) impondo-se como categoria de valor e fazendo ver que a antítese não estava na contradição com o Outro, mas na metastasia de seu próprio crescimento.

A dialética baudrillardiana deve ser entendida nessa proposição, ou seja, que, na realidade, não há homogeneização daquilo que é impossível de não ter antítese - o sistema - e por isso, no fundo, nada ainda foi superado.
Baudrillard, mais que constatar as contradições metabioticamente(sic) implícitas no sistema, entra no próprio movimento da exacerbação do momento fractal, e torna escrachado ${ }^{11} \mathrm{o}$ leviatã que realimenta as redes: o simulacro, essa espécie de hipermercantilismo de tudo. Isso fica claro quando o autor afirma: "Em toda a parte, o que foi liberado o foi para passar a pura circulação, para entrar em órbita. Com certo recuo, pode-se dizer que o fim inelutável de toda a liberação é fomentar e alimentar as redes. As coisas liberadas são fadadas à comutação incessante e, portanto, à indeterminação crescente e ao princípio de incerteza". Esse é o verdadeiro sentido da suposta "revolução": a incerteza, a ascensão e queda de coisas que passam e se intensificam, ao mesmo tempo e a uma velocidade intangível pela assimilação, estabelecendo um "estádio fractal", um campo epidêmico de valores ordenadores que se assemelham à "desordem metastática, de demultiplicação por contigüidade, de proliferação cancerosa (que já nem obedece ao código genético de valor)".

O que mudou, na realidade, foi essa noção do espaço e do tempo, pois agora é possível vivenciar a história factual intermediada pelas opções telárias que substituem a dialógica. Tal entropia traduz-se pelo cerne do processo que mantém a resistência passiva das massas, que, sem lideranças, tendem a perder as identidades nacionais ${ }^{12}$ : é a fetichização do fetiche. $\mathrm{O}$ valor referencial (as relações de classes), a rigor, não desaparece, apenas dilui-se para outra forma. Daí a perplexidade ser o elemento que se interpõe na ação, e a impotência, o seu dimensionamento que remete para além da possibilidade da reação, verdadeiro fator de sustentação da ordem global. A racionalidade não acompanha a velocidade das proposições, sobretudo tecnológicas, é preciso 'agarrarse' em alguma coisa, pois o randômico é insuportável, por isso a refuncionalização das reproduções dessimbolizadas torna-se o modelo. E o simulacro, cuja razão metastática é o sentido original da "pós-orgia", intensifica a pseudoconcreticidade e, tal qual mágica, desaparece com os sujeitos acionais. Por isso a pertinência do 'pagar para ver', de Baudrillard, quando afirma: "quero saber como esse sistema funciona, neutraliza-se ou é desestabilizado pelas próprias energias".

O ponto nevrálgico continua na condição de que "a revoluçãoé uma construção deidentidade, 
mas justamente aí surge o pânico, proveniente de que toda a identidade é animadora", isto é, toda identificação é uma força acionária e é justamente aí que "as forças identificatórias com os universos isolados, onde o eu é [somente] identificado a si mesmo", se impõem numa diferença estrutural que se "prolifera ao infinito, na moda, nos costumes, na cultura." Nesse processo, tudo, inclusive a alteridade, cai sob a lei do mercado, da oferta e da procura: "na revolução é preciso perguntar: 'eu sou alguém, mas quem?' (...) A partir do momento em que é necessário responder por si mesmo a essa questão quase ontológica, metafísica, tudo fica flutuante e aleatório". Essa é a lógica que o atual globalismo impõe, que se diferencia de todas as outras tentativas de dominação de povos e civilizações, historicamente conhecidas.

Em tal dinâmica se reconhece a aproximação da teoria de Baudrillard com a Pós-história, pois sua lógica consolida-se não propriamente no desaparecimento do sujeito, mas no seu esmaecimento, na medida em que já não parece ser ele mesmo e, sim, só o 'mesmo'13. Nessa condição, o sartreanismo é travestido de uma perversidade quase insuportável, pois "já não há o Outro como superfície refletora; a consciência de si está ameaçada de irradiação no vácuo", e ao invés de 'me reconhecer' nesse Outro, é exatamente ele que "detém de imediato tudo o que nunca nos será dado saber". Essa seria a perda irremediável de toda possibilidade de identidade (de nação, de grupo, de classe...), a própria significação enquanto sujeitos históricos, (realmente a surpresa é bem maior!):

Haveria em todo o sistema, em todo indivíduo, a pulsão secreta de livrar-se de sua própria idéia, de sua própria essência, para conseguir proliferar em todos os sentidos para extrapolar em todas as direções? Mas as conseqüências dessa dissociação só podem ser fatais. Qualquer coisa que perca a própria idéia é como o homem que perdeu a sombra - cai num delírio em que se perde.

Entende-se que esta é a tentativa da consolidação da globalização mais humanamente frustrante que Baudrillard captou muito bem como a perda da própria idéia de ser. No entanto, ele continua a afirmar: "a análise de Marx continua idealmente indiscutível". Dir-seia mais: sem Marx, Baudrillard não existiria, à medida que ele é a partir de... Todavia, sua visão consegue recolocar o movimento do Capitalismo numa outra órbita, onde a interpretação, agora, se faz pela constatação que o capital junto com a burguesia "geraram uma sociedade sem classes, mas bem diferente da que teria resultado de uma revolução e da negação do proletariado como tal". Esse é o significado mais profundo do simulacro em

Baudrillard, do "ideal-clone", do delírio máximo do poder: acabar com a idéia das relações de classes, já que é impossível terminar com a concreticidade do fato. Por isso, se houve a "orgia", como tal, há o seu reverso doentio, a "pós-orgia", onde o fenômeno extremo, o idealclone, vem a ser "o sujeito expurgado do outro, expurgado de sua divisão e condenado à metástase desimesmo, àpurarepetição",àasfixia social total, induzindo à constatação de que, nessas condições, a rigor, ninguém sobrevive. Daí a dúvida, se as classes sociais foram, realmente, abolidas, se desapareceu o proletariado, as mais-valias, a alienação, e assim por diante, principalmente, porque a universalização do capitalismo implica, da mesma forma, em não apagar toda a outra potencialidade. Ao contrário, na mesma proporção, impõe seu crescimento, ainda que paire sobre os pensamentos mais avançados uma tendência a desacreditar nessa possibilidade.

As brechas produzidas pela globalização deixam escapar lavas de um vulcão que, mesmo parecendo extinto, faz sentir seu refluxo através de movimentos sociais, como, por exemplo, o $\mathrm{MST}^{14}$, e no contraposto do Globalismo, na mesma dimensão, impõe-se um Fórum Social Mundial15. Do contrário, não somente a idéia torna-se avassaladora, como nos remete diretamente ao real significado de uma Póshistória.

A Pós-modernidade não foge dessa mesma noção de sociedade global, embora não tenha uma 'data' tão definida, confundindose, ainda, com o auge da Modernidade, podendo-se vislumbrá-la mais como um ritus de passagem pelos sintomas, sobretudo, de cunho artístico-cultural, do que como um referente da mudança histórica concretizado na globalização. Para Coelho (1990, p. 58), o conceito de Pós-modernidade, na concepção de Marx, está intimamente ligado ao de Póshistória, ao referir-se à contemporaneidade alemã do século XIX. Eles são indissociáveis, uma vez que a Pósmodernidade, neste caso, 
traduz os processos de produção impostos originariamente pelas Revoluções Industriais, cujas rupturas ocasionaram o surgimento da era industrialmente revolucionária.

Segundo Coelho (1990, p. 60), essa situação não somente reafirma o capitalismo como a nova ordem, como faz emergir a sua força imperialista "numa alteração qualitativa profunda no processo histórico, visto como dividido em dois momentos: um pré-histórico e outro pós-histórico".

Tais conceitos, eram visivelmente coadunados à época e realmente representavam as profundas transformações que estavam para ocorrer, tanto em cunho material (pela inserção da máquina no trabalho humano) como em cunho relacional, com a nova ordem. Por isso, entende-se por que para Arnold Toynbee (apud Coelho p. 60) nos anos 40, "o período pós-moderno começou nos últimos vinte e cinco anos do século XIX e definiu-se exatamente pelo assentamento do imperialismo e conseqüente declínio do Estado Nacional, superado por um processo de interação internacional". Independente dessas posturas que conseguiram compreender o significado das profundas mudanças que o capitalismo impôs em seu tempo e, de certa forma, no vislumbre de uma época ainda por vir, entendese que o imperialismo, com toda sua força, só vai se sedimentar em meados do século XX. A

Segunda Guerra Mundial vai ser um marco definidor da Pósmodernidade e da Pós-história, na concepção atual dos termos, porque o movimento estruturador de uma consecução Pós-histórica da sociedade capitalista implica transformações principalmente tecnológicas, as quais configuram uma nova etapa do mesmo capitalismo, considerada pós-industrial. Para melhor caracterizar esse instante, é bom lembrar a entradaem cena, por exemplo, daTV, o principal marco das transformações. Nesse aspecto, já se teve a oportunidade de escrever sobre o "processo de retração da comunicação"16, exatamente para demonstrar as implicações que ocorreram a apartir desse objeto estranho que se inseriu no quotidiano das pessoas, como um membro da família, alterando a qualidade das relações humanas. Fomatadas para o isolamento, o estágio terminal da sociabilidade dialógica e crítica se configura no mais recente substituto da TV, o computador, como forma homogênea de linguagem, tendo na Internet a apologia das realizações neoplatônicas. A inserção de novas tecnologias desconfigura, por um lado, as tradicionais relações de produção de vida e, por outro, reformula conceitos valorativos que permeavam, até então, as culturas e suas manifestações estéticoartísticas.

Assim, pelo mesmo processo, a Póshistória propõe ir muito além do conceito de imperialismo, para o qual ainda estaria exposta a face definida e dura dos donos do capital (o verdadeiro, não o legítimo sujeito da história), numa espécie de clonagem, onde todos se incorporam simbolicamente, como pedaços dessa célula-tronco. É justamente a indefinição que torna este instante viável, ou seja: "quando as coisas, os signos, as ações são libertadas de suas idéias, de seu conceito, de sua essência, de seu valor, de sua origem e de sua finalidade, entram, então, como auto-reprodução ao infinito", e o entorno limítrofe impõe-se no próprio 'terratorial' ${ }^{17}$ e, nessa compleição, o globalismo assume uma identidade nacional /mundial.

Depreende-se dessas noções que o processo histórico, por isso processo, é um movimento intermitente, isto é, contínuo, mas não linear propondo permanentes mudanças estruturais, embora nem sempre perceptíveis. Os dois conceitos, Pós-moderno e Pós-histórico, imbricados um no outro, não são sinônimos, mas expressões das transformações que estão ocorrendo numa mesma época e que começam a aflorar na superfície das percepções materiais, como, por exemplo, nos acontecimentos dos anos 60.

Principalmente nas sociedades mais desenvolvidas, naquela década, observam-se ebulições políticas, como os movimentos de esquerda manifestando-se nas mais diferentes oportunidades, movimentos de gênero exigindo novos espaços sociais, transgressões na linguagem artístico-cultural, e, nos costumes, novas formas de expressões corporais processando uma mega-liberação, sobretudo feminina.

Esse é o momento da passagem, ritual de morte, o instante, o interstício entre a orgíaca Modernidade - a história da inserção do ser humano, "(...) o poder da vida, a fecundidade do seu trabalho, a densidade histórica da sua linguagem" - e a explosão final. Passando-se, em seguida, à "pós-orgia" que mais se coaduna com o sentido do cinema underground norteamericano, em cuja figura imóvel de um homem dormindo durante horas emerge a exacerbação da imagem e, conseqüentemente a perda do 
significado individual (do coletivo, do indivíduo), pela "promiscuidade consigo mesmo", de forma objetal, desprovida de significação: o vazio. Em Baudrillard, uma das ilustrações mais significativas desse imobilismo apresenta-se na "... imagem do homem sentado, contemplando, num dia de greve, sua tela de televisão vazia" o que "constituirá no futuro uma das mais belas imagens antropológicas do século XX".

Outra contribuição para a explicitação deste momento de póshistória vem de Michel Foucault, para quem, até o final do século XVIII, o homem não existia como sujeito acional, tratando-se de uma persona muito recente com menos de duzentos anos: "uma coisa em todo caso é certa: o homem não é o mais velho problema nem o mais constante que se tenha colocado ao saber humano" (1992, p. 404).

Eis o sentido da história, na medida em que, para ele (1992, p. 403),

(...) toda a 'epistemê' moderna - aquela que se formou por volta do fim do século XVIII e serve ainda de solo positivo ao nosso saber, aquela que constituiu o modo de ser singular do homem e a possibilidade de conhecê-lo empiricamente, (...) estava ligada ao desaparecimento do Discurso e de seu reino monótono, ao deslizar da linguagem para o lado da objetividade e ao seu reaparecimento múltiplo.

A história está ligada à multiplicação dos significados e, por conseguinte, à diversidade de grupos sociologicamente definidos, cujas relações concretas impossibilitam a monocórdia do discurso imperativo, o que resulta a importância de se compreender os atuais instrumentos mediáticos como obstáculos a qualquer possibilidade de discórdia. Ainda que resguarde a crítica para um 'depois', Foucault (1992, p. 403) estima a possibilidade dalinguagem surgir com "insistência cada vez maior numa unidade...", o que seria o mesmo que acabar com as idiossincrasias dos grupamentos, com suas identidades, únicas com poder real de interferir na dialética da totalidade: "o homem só compôs a sua figura nos interstícios de uma linguagem em fragmentos", sendo o desaparecimento dessa figura o começo de uma nova 'epistemê' calcada na tecnocracia.

Nessa compleição, apresenta-se, como sustentação a mais nova performance do recorte de conhecimentos e seus modelos pós- modernos, o mais alto grau de alienação, o indiferentismo moral, político, social e intelectual, característica predominante do fim da história e sua iminente possibilidade. Seguindo, ainda, o pensamento foucaultiano, pode-se fazer uma ilação com a "pós-orgia" de Baudrillard, nos termos de uma proliferação da mesmice, pelo simulacro sígnico, quando Foucault (1992, p. 404) indaga, por exemplo: "Tendo o homem se constituído quando a linguagem estava voltada à dispersão, não vai, ele, ser disperso quando a linguagem se congrega?" A congregação, que leva ao conceito de homogeneização, implícito na composição positiva da globalização, não seria, na realidade, o que Foucault considerou "(...) o sinal de que toda essa configuração vai agora se deslocar, e que o homem está em via de perecer, na medida em que brilha mais forte em nosso horizonte o ser da linguagem?" Ou, baudrillando de vez, a possibilidade do simulacro, o estádio fractal? Nesse caso, fica explícita, também neste autor, a Pós-história.

\section{Alguns referenciais materiais da globalização}

Os mecanismos para a definição sintônica da ordem global impõem-se pela multiplicação da informação ao infinito, que não é o mesmo que diversidade cultural, diversidade de linguagem, menos ainda, conhecimento referenciais necessários à própria sobrevivência -, porque, essa aparente abundância de dados é o mais forte indicador da despersonalização das individualidades (inclusive de classes), da aculturação disruptiva das identidades e da fragilização das autonomias nacionais. A globalização se expressa de diferentes formas, principalmente através da informática que revela a busca da uniformização como recurso de controle. Pode-se fazer um parêntese aqui, para reparar que a cibernética, como fonte explicativa dos sistemas informacionais, tem seu conceito etimológico ligado a uma palavra grega, cujo significado quer dizer 'aquele que controla o navio, o timoneiro'. Fechando parênteses, pode-se afirmar que o desenvolvimento das tecnologias, nessa área, traz em si esse sentido de manejo; em outras palavras, quanto mais avançados tais instrumentos, maior o poder de controle.

É nessa direção que se busca compreender os referencias materiais da globalização, principalmente a partir da "pós- 
orgia" de Baudrillard, como status do instante histórico que se impôs pela universalização do capitalismo. Nesse sentido, Finley (1986, p. 37) contribui à crítica, ao afirmar que"o aspecto mais importante do impacto social tem de ser o das relações de poder e controle social que surgem de toda inovação tecnológica. A ordem social é uma ordem de relações de dominação, poder e controle", da qual emergem os questionamentos sobre a aculturação, as forças identificatórias e as autonomias nacionais. A lógica continua a mesma, o capital necessita ser reproduzido, mantendo e abrindo novos mercados de produção e consumo. A mudança se dá nas relações de trabalho, na qual o computador, com todas as suas variações, passa a ser o meio mais eficaz para o controle das totalidades nacionais. Aliás, esse é o apanágio, a condição sem a qual o sistema globalizado não poderia funcionar e, em tal esfera, as materialidades se tornam visíveis pela aparência, pela dependência e pela imposição que causam a todos os setores da sociedade, inclusive atingindo as individualidades.

O sistema financeiro, para o qual as organizações bancárias são expressivas formas dessas materialidades, amparado pelos sistemas computacionais, fecha um circuito informacional de rapidíssima circulação, com o qual os sujeitos não mais disponibilizam da credibilidade pessoal, mas da dependência de uma avaliação maquinal, despersonalizada e homogênea. A sua face mais definida são os organismos centralizadores de informações cadastrais, especialmente criados com essa específica finalidade, como, entre outros ${ }^{18}$, o Cerasa, os SPCs, em níveis nacional, regional e municipal.

No contraposto, estão o cartão de crédito, os cheques especiais, em redes nacional e internacional que controlam um comércio sem fronteiras. Essa é a mais fiel imagem do simulacro da igualdade, que corresponde à imagem do mundo atual que, segundo Gindre ${ }^{19}$, "se divide entre incluídos e excluídos". O autor explica que "os consumidores formam uma 'classe' planetária cujos laços de pertencimento não estão mais atrelados a limites geográficos. Por isso, devem ser buscados onde quer que estejam. Usuários do American Express Card podem estar na Cidade do Cabo, New York ou Shangai e possuem muito mais identidade entre si do que com seus conterrâneos dos bairros pobres destas cidades". Inclui-se, aí, a recente lista dos "melhores clientes", elaborada pelo Banco Central do Brasil, para os quais serão oferecidas algumas benesses nas taxas cambiais e nos juros.

Essas diferenças impossibilitam o exercício da defesa (leia-se da cidadania) que poderia ser, da mesma maneira, institucionalizada pelo lado oposto, mas totalmente inviabilizada pela hegemonia do mercado sobre as individualidades, sejam empresariais, pessoais, ou grupais, que acabam reféns do sistema na busca da própria sobrevivência: não há poder de barganha. Em outras palavras, os critérios de bom e de mau, o que define a exclusão ou seu vice-versa, são apenas uma questão de ótica, segundo a qual os interesses dos que mantêm o poder serão sempre norteados pelo status econômico. A rigor, a questão tem que ser entendida no processo do estádio fractal, ou na intensificação do valor-signo, onde "a inserção do trabalho com informação torna o processo, ainda mais, imaterial, cada vez mais virtual, facilitando, definitivamente, a exclusão e o mascaramento do sistema como seu responsável direto"20.

Embora o sistema financeiro seja o lado deflagrador desse processo, na medida em que ele não somente interfere, mas se impõe diretamente na totalidade da sociedade, outros organismos, ao longo da história, têm se apresentado com a mesma função de banco de informações com vistas ao controle, como, por exemplo, o caso da CIA, tratando-se de um órgão de informação para assuntos exteriores dos EUA, que tem seus poderes comprovados, inclusive pela responsabilidade direta na queda de governos de diferentes países, principalmente na América Latina, atendendo aos interesses de seu dono. No Brasil, em que pese o fim do $\mathrm{SNI}$, foi criada outra agência de inteligência - a ABIN - cuja função, entre outras é a de 'zelar' pelas urnas eleitorais, o que tem criado uma certa celeuma nos meios políticos. Na era da informática, pressupõe-se que esses organismos potencializaram suas forças, o que sempre causa um desconforto. Porém, a mais pósorgíaca das materialidades dessa conjuntura é a comunicação de massa, cujos meios estão nas mãos de não mais do que vinte megaempresas, no mundo todo. Por isso, Baudrillard (apud Silva, 1993, p. 170) descorda frontalmente com a Teoria do Agir comunicativo de Jürgen Habermas, quando afirma:"não possoacreditar (no consenso), pois vejo a comunicação ao contrário. 
Uma rede sem espaço à diferença, na qual é criada artificialmente o consenso". Já se teve oportunidade de expor que"o simbólico seria uma concepção unidirecional, absolutilizada numa única ideologia: a do patrão"21. Portanto, o sentido de 'consenso' estaria intimamente ligado à Cultura de Massa, ainda sob a influência da Teoria Crítica, e que, portanto, seria "um kitch voltado para as emoções primárias suscitadas pelas representações acabadas e esmaecidas no medianismo (mediocridade) das criações artístico-culturais, de fácil absorção, sem requerer esforços reflexivos ou empenhativos a compreensões mais complexas"22. De outra forma, Bagdikian (1993, p. 25) observa que as conexões sociais são reduzidas a "um pequeno número de circuitos", nos quais "os proprietários desses conduítes preferem difundir material de que são donos ou que possa servir a seus objetivos" particulares, o que vem, no frigir das idéias, dar no consenso artificial cuja função é "extasiática e alienadora"23.

Oconjuntotodoépanópticoerevelaatéonde chegou o processo do 'globalismo', pelos fios das redes dos "senhores da aldeia global"24. De um lado, uma ordenação informacional totalmente aferida por aqueles interesses. Do outro, pelo mesmo motivo, a fragmentação de informações, assim entendida, pela presença de um sistema altamente entrópico que recria o isolacionismo como suporte do procedimento vigilante ubíquo e internalizado. Para Foucault (1995, p. 80), esse procedimento existiu nos hospitais e nas prisões desde o século dezessete. Para Áries (1981), essa prática também tornou-se normal nas escola, principalmente para adolescentes e em outras instituições que previssem a individualização como medida de assepsia social e educação conformativa, a partir do final do século XVIII. À medida que se aprofunda o processo do 'globalismo', a compreensão se estende para a percepção de que não se faz mais necessário um observador explícito, ou seja, o panopticismo também se pósmoderniza, no sentido de que os indivíduos internalizam as regras impostas porque já se sabem constantemente vigiados, impotentemente controlados, a ponto de não reagirem aos constantes engodos a que são submetidospelosistema, até pelo emperramento da máquina legal, único mecanismo que resta para os mais atingidos e inconformados. Esta é a seqüela mais chagada do simulacro de Baudrillard: a aculturação desruptiva. Por isso, em relação aos "senhores da aldeia global", segundo Bagdikian (1990, p. 38):

Nem César, nem Hitler, nem Franklin Roosevelt e nem qualquer papa tiveram tanto poder como eles para moldar a informação da qual tantas pessoas dependem para tomar decisões sobre qualquer coisa - desde em quem votar, até o que comer.

Daí o paradoxo, pois quanto maior o grau de informações, desconexas e sem recursos à reflexão crítica sobre a realidade que as produz, maior é o domínio. Pode-se verificar tal situação, ainda, na medida em que aumentam os aparatos facilitadores, como os sistemas fechados (e mesmo os aberto) de televisão e, agora, a educação on-line, onde se separa cada vez mais o ser humano do seu universo cultural próximo. Em si, tais mecanismos não podem ser nocivos, mas a referência ao domínio nada diversificado das fontes explicita pelo menos quase tudo.

A próxima questão se localiza na fragmentação das identidades, por conseqüência nas periclitantes autonomias nacionais. Na Reunião do Fairmont, em San Francisco da Califórnia, em 1995, da qual HansPeter Martin e Harald Schumann foram os jornalistas testemunhais, essa questão confirmase nas palavras de John Gage ${ }^{25}$ (apud Martin \& Schumann, 1999, p. 19):

cada qual pode trabalhar conosco quanto tempo quiser, também não precisamos de vistos para o nosso pessoal no Exterior (...) Empregamos nosso pessoal por computador, eles trabalham nocomputador e também são demitidos por computador.

Essa concepção de relação de trabalho liquida com qualquer tentativa de organização sindical. As identidades de classes ficam esmaecidas, como já se referenciou anteriormente, junto com a noção de poder que se individualiza, negando as forças acionais transformativas, historicamente processadas em relações concretas e não virtualizadas. Impõe-se um discurso falacioso que induz a uma noção de competência, cujos critérios não estão, em nenhum momento, esclarecidos, tornando essa competência uma espécie de jogo fatal. Quanto às autonomias nacionais, afirmam Martin e Schumann (1999, p. 9): 
Governos e suas normas para relações trabalhistas já teriam perdido qualquer significado. Ele (Gage e similares) empregaria quem precisasse, em dado momento, onde estivessem os candidatos, (...). De todas as partes do planeta a firma estava (na ocasião da reportagem) recebendo, por computador, solicitações de emprego que falavam por si sós.

Complementarmente, lanni (1998, p. 48) reafirma o sintoma da perda das identidades e das autonomias: "o Estado-Nação não só é redefinido, mas perde algumas das suas prerrogativas econômicas, políticas, culturais e sociais, debilitando-se". Para Marilena Chauí, a questão volta, novamente, para o papel da informação. Segundo ela (1993, p. 146), seria necessário saber mais a fundo "como os indivíduos recebem a informação; quais informações são dadas; quando são; quem as dá; com que fim as recebem - para serem fixadas em certos pontos determinados do sistema social ou para dar-Ihes liberdade de trânsito entre um setor e outro". Concordase plenamente com essa posição, porque o problema só pode se mostrar, em sua verdadeira amplitude, à medida que os questionamentos surgem, aprofundando o debate. Assim, também pergunta-se, junto com aquela autora (1993, p. 46): "podem os indivíduos tirar igual partido das mesmas informações, ou a homogeneidade serve apenas para ocultar uma desigualdade social e econômica reforçada pela própria 'igualdade' de informações, aceita como algo de que nem todos poderão tirar frutos?".

A compleição dessa realidade leva ao que Chaú (Op.Cit:147) considera o paradoxo entre "o discurso competente (...) e a massa" e se reafirma, porém com outras intenções, nas declarações da tal "Reunião do Fairmont" (apud Martin \& Schumann, 1996, p. 10-11), quando "a sociedade de 20 por 80" passa a ser um fato mais que previsível. Para Chauí (1993, p. 147), a

noção de competência tem a função precisa de marcar a desigualdade numa esfera que não é mais aquela tradicional da ideologia burguesa (a desigualdade natural das capacidades e talentos), mas uma outra, produzida pela sociedade planificada e organizada: a desigualdade entre os detentores do saber e os despossuídos.
Essa já não é, propriamente, uma preocupação para os promotores da globalização, visto que, segundo aqueles jornalistas (1993, p. 10-11),

(...) a visão de inimagináveis massas de desempregados é encarada com naturalidade. Não há executivo de carreira e bem pago, dos setores de ponta e dos países com futuro promissor, que ainda creia na criação de empregos novos e decentes em mercados tecnologicamente avançados - seja qual for a especialidade profissional.

Eis aí a analogia ao "20 por 80", significando que "vinte por cento da população em condições de trabalhar no século 21 bastariam para manter o ritmo da economia mundial". Os outros $80 \%$ são preocupação para a beneficência. Isso implica na qualidade da relação que se estabelece e na competição de competências determinadas, não mais pelas necessidades institucionais humanas, mas, segundo Chauí (1993,p. 146), pelo sistema, isto é:

seja qual for o estatuto econômico, a posição dentro de um sistema global de dependências sociais, um indivíduo participa da vida social em proporção ao volume e à qualidade das informações que possui, mas, especialmente, em função de sua possibilidade de acesso às fontes de informação, de sua possibilidade de aproveitá-las e, sobretudo, da sua possibilidade de nelas intervir como produtor de saber.

O círculo torna-se vicioso, porque seria necessário retomar sempre a mesma ponta da espiral, e o 'detour', invariavelmente, levaria ao mesmo ponto: à "armadilha da globalização". De um lado, o 'G8', preconizando fazer da globalização um sucesso que beneficie a todos; de outro, centenas de milhões de pessoas para quem o progresso global inexiste e, possivelmente, jamais existirá. Contudo, acreditase (e só pode ser uma questão de crença) que a realidade imediata de certas categorias de trabalhadores e a sua atividade criadora permanecem subjacente, independente das condições que lhe são impostas pela sociedade globalizada. Aliás, Baudrillard (In: Silva, 1993) até ensaia uma opinião a respeito da situação do 
Brasil: "parece que no Brasil frações inteiras da população, em tese, estão fora do circuito da circulação programada. São margens onde há possibilidades de inventar a troca simbólica, a crítica, de agir politicamente e criar". E, mesmo que a divisão de classes e as identidades comunitárias pareçam desmaiadas, ainda assim, por se estar sob a égide do capitalismo, dialeticamente a possibilidade antitética sempre estará presente, porém não ingenuamente, porque, neste contexto, o simulacro faz parte do jogo.

\section{O que sobrou da orgia?}

Hoje, afirma Baudrillard, "passado o momento explosivo (...) da liberação em todos os domínios (...) se fosse caracterizar o atual estado de coisas eu diria que é o da pós-orgia". O jogo - se é que existe - já não é o das individualidades (nem dos indivíduos, nem dos coletivos), mas o da individualização, devido à absolutização das liberações. As identidades estão perdidas em meio aos caminhos já percorridos da "produção e da superprodução virtual de objetos, de signos, de mensagens, de ideologias, de prazeres" sendo o sentido mais patológico das massas até por se constituir, segundo o autor, no "sinal do fim do social, na medida em que a energia social se investe de uma configuração em que o próprio social não tem mais nome...."

Pode-se dizer que se trata de uma visão pessimista, porque nos apresenta um novo sentidodovaziopara oqualseencaminhamtodas as sociedades que perderam ou estão perdendo as humanidades como centralidade social. Tal enfoque reafirma a já expressa noção de fim da história, porque sai de cena o ser humano, a possibilidade da superação das contradições do capitalismo, em especial a luta de classes, para dar lugar ao tecnocentrismo, onde a virtualidade se impõe como a forma comunicativa - ou a novidade do valor de troca na conformação de uma epidemia -, que é a exaltação suprema da fetichização. Se com a Modernidade o homem passa a existir como objeto e sujeito epistemológico e histórico, ou seja, se na "orgia" de Baudrillard, quando acontece o momento real das explosões da liberdade em todos os sentidos, "política, sexual, das forças produtivas, das forças improdutivas, da mulher, da criança, das pulsações inconscientes, liberação da arte", agora, superado esse momento, o que resta é o simulacro de tudo isso: "fingir que prosseguimos acelerando, mas na realidade, aceleramos no vácuo porque todas as finalidades da liberação já ficaram para trás".

O que se impõe, na 'nova era', é o universo da tecnocracia, das redes e, sobretudo, do mítico progresso, divinizado desde o século XVIII, justificando todos os rituais. Para Horkheimer e Marcuse (apud Merquior, 1990, p. 50) esse conceito começa a ter novos contornos: "o que se apresenta como progresso, o insistentemente novo que se oferece, permanece, em todos os seus ramos, a mudança de indumentária de um sempre semelhante; em toda parte a mudança encobre um esqueleto no qual houve tão poucas mudanças como a própria motivação do lucro desde que ela ganhou ascendência sobre a cultura". Desde aí já se concretiza a noção de simulacro e seu principal suporte, o panopticismo - controle exacerbado -, através de aparatos tecnológicos em permanente renovação, que justificaram e justificam todas as dependências e submissões, porque se colocam como instrumentos à disposição do 'progresso', mas, na realidade, segundo os frankfurtianos (1990, p. 51) "se transformam numa investida contra a natureza e contra o próprio homem".

Por outra, entende-se que 'progresso' é um ponto de chegada, é o fim do processo para o qual todas as forças convergem. Como esse tempo/espaço nunca chega, dáse razão à mudança da indumentária, com a qual vem coincidir o próprio 'globalismo' e, por conseguinte, o simulacro, porque as realizações só foram simbólicas. Aliás, é na exacerbação da simbologia que o ser humano, na possibilidade de um espaço virtual ou imaginário, consegue concretizar todas as utopias. E por isso que, ao captar a "pós-orgia" como o 'dia seguinte' de todas aquelas realizações, Baudrillard entende que se trata do "estado da utopia realizada, de todas as utopias realizadas, em que é preciso paradoxalmente continuar a viver como se elas não o estivessem..." ou, "acelerarnovácuo". Essaé, segundo se entende, a exposição mais profunda do sentido daquilo que se convencionou chamar de Globalização, porque, se as utopias se realizaram (se realmente assim ocorreu), elas não convergiram para a totalidade. Como o sistema só se sustenta na expansibilidade, o 'progresso' tem que continuar ainda que na repetição, sendo preciso o controle absoluto para impedir a desviância ${ }^{26}$ que por muitos anos esteve iminente. Mas, como destruir totalmente expectativas historicamente construídas? 
Daí a permissividade para todos os "neos", como se cada um deles fosse impune à sua própria história (neoliberalismo, neonazismo, neoplatonismo, neomarxismo, e assim por diante). Mesmo não se definindo propriamente como um intérprete da planetarização da cultura, o que poderia enveredar pelas definições da Indústria Cultural, nem aportando a questão exclusivamente sob a ótica economicista, o sentido mais abrangente possível da crítica de Baudrillard, porque explicita o novo estádio fractal (epidemia do valor), é a inserção do ser humano num anonimato degenerativo ${ }^{27}$, reconceituando a noção de "massas", na qual "só há grau zero do político, a esse nível de referência absoluta, de onipresença e de difração em todos os interstícios do espaço físico e mental".

Essa é a conseqüência mais fatalmente virótica da Pós-história, não por decretar o espaço último da Modernidade onde, no lugar das possibilidades de transformações pela assunção das personalidades diversificadas dos grupamentos e classes, que são os referenciais dos sujeitos e o lugar das contradições, fazer acreditar que se instaurou esse grau zero do político. Então, só resta o paradoxo da busca eternizada de um progresso que nunca chega.

A partir das elucubrações sobre os fenômenos extremos de Baudrillard, é preciso indagar até que ponto países terceiromundistas, como o Brasil, enquadram-se totalmente nesta perspectiva de globalização e Pós-modernidade. Trata-se de uma pergunta que abriria um barril de questionamentos, à medida que ainda sonhamos com a "orgia", e dela o que sobrou foi um bafo ocre do outro. Para nós, o simulacro poderia, ainda, ser a própria busca da realização das liberdades, só que os caminhos da ordem não se subvertem fora dela, e o paradoxal dessa situação, afirma Baudrillard, é que o outro já esgotou seu limite e só the resta "... o estado de simulação, aquele em que só podem repetir todas as cenas porque elas já aconteceram real ou virtualmente".

E, para nós, por uma questão de sincronia abrangente do sistema, acaba sobrando um faz-de-conta muito mais simulado ainda, pois na condição da dependência dessa lógica, "o segredo do outro é que nunca me é dado ser eu mesmo e que só existo por declinação fatal daquilo que vem de outro lugar" (por analogia não estão presentes, nesta expressão, as próprias imagens do FMl e do Banco Mundial?). $\mathrm{Na}$ globalização, em que Schnitzler (apud
Baudrillard,1992, p. 175) afirma que estranhos têm o mesmo destino, ainda que, por indução ${ }^{28}$, responde-se com Baudrillard: o papel do terceiro mundo neste jogo é o de reproduzir fatalmente, indefinidamente e indiferentemente, as mesmas idéias, os mesmos fantasmas; "reprodução de sonhos que doravante ficaram para trás e que, no entanto, devemos reproduzir numa espécie de indiferença fatal". Mas, a rigor, que ideais, que fantasmas, que imagens, que sonhos, afinal, ficaram para trás?

Não teríamos, porventura, 'embaixo do tapete', a pulsão da crença na transformação, ainda que em outros moldes, mesmo premidos por um sistema globalizado que se impõe com força coercitiva, e mais, disruptora de objetivos e necessidades locais? Afinal, há coisas que não foram superadas e que só no plano das ideologias assumem a liderança por decretação do outro, e nos fazem acreditar que a essencialidade mudou de lugar, não é mais humana. A questão posta, neste momento, situase no onde e com quem está a força: no desvio, no simulacro de algo que para nós não ocorreu? Ou na concretização de uma quotidianidade que a cada passo se reveste mais e mais de uma espécie de antropofagia que nos engole na volúpia de saciar o poder e a ganância. Esses sim, são os suportes reais das "orgias" e "pósorgias", portanto, da mesmice.

Sobre o que restou da "orgia", então, podese dizer que, no simulacro, foi uma suposta harmonização de interesses globalizados, que não passa de mais uma tentativa para manter a força centrípeta do sistema, através da ideologização das massas anônimas: um esforço à homogeneização. Já na realidade concreta, esta força tende a se esfacelar, porque, no que pese a retomada de fôlego do capitalismo através dessa tentativa, a homogeneidade e a harmonia não existem de fato. Continuam postas as mesmas (e velhas?) contradições, embora não seja à toa que Lipovetsky ${ }^{29}$ coloca como se fossem novas, quando afirma que

hoje, as grandes preocupações são com o desemprego, com a insegurança, com o futuro, com a educação das crianças, com uma nova qualidade de vida e com novas formas de espiritualidades.

Surpreendentemente, as diversidades políticoculturais ainda constituem a riqueza humana, pluralizam idéias e ideais, e, conseqüentemente, 
fazem presentes expressões de sublevação. Então, ainda é possível fazer um outro mundo, "se a gente quiser".

\section{Notas}

1 Propriedade fundamental dos organismos vivos pela qual podem mudar de maneira ativa e reversível as relações de posição do corpo ou de suas partes com respeito ao ambiente. É uma dessas expressões da propriedade da matéria viva de reagir aos estímulos.

2 Apud Buadrillard, 1992, p. 181.

3 No sentido de imagem fantástica de um morto.

4 Algumas das figuras criadas por Warhol foram os imensos posters de artistas famosos como o de Marylin Monroe. Neles, a dessimbolização fica totalmente explícita na medida em que capta, muito mais que as formas, uma espécie de sobrevida ao ícone. Propõe movimento. Já não se trata mais de uma simples reprodução fotográfica; a figura impõe a presença do próprio sujeito representado.

5 "O que é tecnicamente possível, não é por esta razão, moralmente admissível". Donum Vitae, (1987).

60 vocábulo original é demultiplicador, cujo significado refere-se ao câmbio capaz de reduzir a velocidade de um motor em favor de maior força.

7 Expressão de George Orwell em seu livro '1984'. Embora referenciando o Estado totalitarista stalinista, a perspectiva do Grande Irmão sempre pareceu adequar-se, também, à própria expansão do Capitalismo.

8 Para Jean-Paul Sartre, "quem diz' instante', diz 'instante fatal': 0 instante é o envolvimento recíproco e contraditório do antes pelo depois; ainda se é o que se vai deixar de ser, e já se é o que se virá a ser (...)". Saint Genet, comèdien et martyre. Paris:Gallimaire, (1952, p.9-19).

9 Basta ver as declarações do Presidente dos EUA, George W. Bush, após os atentados ao World Trade Center, se auto proclamando 'defensor do mundo livre', numa direta alusão a 'outro(s) mundo(s)', os países mulçumanos, cuja cultura e religião, completamente diferentes, servem de suporte para a justificativa da guerra insana a eles deflagrada, em nome da luta contra o terrorismo. Não se trata aqui de fazer uma análise desse fato, mas a ideologia do 'bem' e do 'mal' permanece aportando a desova e o fomento da indústria bélica, bem como a conquista de novos territórios, novos mercados, substrato da globalização capitalista. $E$, se for de interesse, o foco poderá ser qualquer outro, como, por exemplo, a América Latina.

10 LeBon, In:DUARTE. Boletim do Museu Nacional. Antropologia. Rio de Janeiro, n01, (agosto, 1983, p.410).

11 Diz-se de indivíduo identificado criminalmente e cuja fotografia fica exposta em quadro na polícia; como aviso ao público, dada a sua periculosidade.

12 Temos, como exemplo mais recente, o caso da Argentina que se encontra em estado pré-revolucionário. Porém, as massas populares sem lideranças não conseguem, pela própria força, reverter nem avançar o processo, o que proporciona, cada vez mais, o avanço da dominação, seja pelas políticas protecionistas ao capital internacional, seja pela quebra de legislações internas, exigência do FMl e Banco Mundial para a ajuda da reconstrução e recuperação de credibilidade dos mercados, seja pelo desmantelamento das potencialidades da interdependência, ainda em construção no Mercosul. E o pacto com a ALCA, idéia subliminarmente imposta, coloca em risco os países vizinhos e pode levar a conflitos. Esta possibilidade não está totalmente fora de cogitação, levando-se em conta as políticas internas dos EUA. Falar mais é redundar.

13 Novamente, a idéia do clone está presente nessas afirmativas.

14 Movimento dos Sem Terra, que ocorre no Brasil, mas de reconhecimento mundial, cujo objetivo referencial é a Reforma Agrária, embora esteja embutida na ação uma proposta revolucionária de cunho socialista.

150 Fórum Social Mundial já teve duas versões:2001 e 2002, na cidade de Porto Alegre, capital do estado do Rio Grande do Sul, cuja temática tem versado sobre a possibilidade de se construir um outro mundo, mais humano, "se a gente quiser".

16 CATTANI, Rosane M. M. R. Comunicação: um universo em retração. Revista ECOS, Pelotas:Universidade Católica de Pelotas: EDUCAT, V.4, N.2 (Ago-Dez . 2000 p. 95 -109).

17 Expressão cunhada especialmente para expressar a extensão do fato. 0 território limítrofe é, por enquanto, 0 planeta Terra.

18 Aqui não se trata de ficar nomeando todos os sistemas que desempenham as funções panópticas da informação. A intenção é a de criar uma imagem do que se entende por essas materialidades da globalização.

19 gindre@indesc.org.br., (2000, p.8). 
20 CATTANI, Rosane Maria Manica Rizzi. Geração das Ruas: o Trozo Social. Tese de doutorado, 14 de junho de 2002. Buenos Aires, Argentina: Faculdade de Filosofia e Letras da Universidade de Buenos Aires.

21 CATTANI, Rosane M.M.R. Reflexões para a comunicação. In: Revista ECOS, Pelotas: Universidade Católica de Pelotas; EDUCAT, V.3, N.2 (Maio-Ago./1999, p.60).

22 Idem.

23 Idem.

24 Expressão de FERREIRA, Argemiro. As redes de TV e os senhores da aldeia global. In: Rede Imaginária, televisão e democracia. 1991, p.155.

25 Diretor da Sun Microsystems, empresa que desenvolveu a linguagem Java de programação de computadores. Conduta social ou anti-social de resistência à aculturação, em grau superior à considerada como média.

26 Conduta social ou anti-social de resistência à aculturação, em grau superior à considerada como média.

27 Degenerar significa perder qualidade, alterar-se, modificarse para mal ou pior, corromper-se ou estragar-se.

28 É bom ressalvar que o Brasil, ou qualquer país da América Latina, nunca foi objeto de estudo de Baudrillard, inclusive dizendo-se não conhecedor dessa realidade. Por isso, a transposição de seu pensamento é por indução.

29 LIPOVETSKY, Gilles. Sedução, publicidade e pósmodernidade. In: Revista FAMECOS: mídia, cultura e tecnologia. Faculdade de Comunicação Social, PUCRS N01 Set. 1994 - Porto Alegre: EDIPUCRS, (1994, p.8)

\section{Referências}

ARIÉS, Philippe. História da criança e da família. Rio de Janeiro: Guanabara-Koogan, 1981.

BAGDIKIAN, Ben H. O monopólio da mídia. São Paulo: Página Aberta, 1993.

BAUDRILLARD, Jean. A transparência do mal. Ensaios sobre fenômenos extremos. 2. ed. Campinas: Papirus, 1992.

Edições 70, 1970.

A sociedade de consumo. São Paulo:

CANEVACCI, Massimo. Antropologia da comunicação visual. São

Paulo: Bradiliense, 1990.
CHAUÍ, Marilena. Cultura e democracia. 6 ed. São Paulo: Cortez, 1992.

COELHO, José Teixeira Neto. Moderno e pós-moderno.2 ed. São PauloL\&PM, 1990.

ECO, Umberto. A obra aberta. São Paulo: Perspectiva, 1971.

FINLAY, Marike. Poder e controle nos discursos sobre as novas tecnologias de comunicação. In: Novas tecnologias de comunicação: impactos políticos, culturais e sócio-econômicos. Anamaria Fadul (org). São Paulo: Summus: INTERCOM, 1986.

FOUCAULT, Michel. As palavras e as coisas. São Paulo: Martins Fontes, 1992.

. História da Loucura. São Paulo: Perspectiva,

1995.

IANNI, Octavio. A sociedade global. 6 ed. Rio de Janeiro: Civilização Brasileira, 1998.

MARTIN, Hans-Peter \& SCHUMANN, Harald. A armadilha da globalização. 0 assalto à democracia e ao bem-estar social. 5 ed. São Paulo:Globo, 1999.

MERQUIOR, José Guilherme. Arte e sociedade em Marcuse, Adorno e Benjamon: ensaios críticos sobre a escola neohegeliana de Frankfurt. Rio de Janeiro: Tempo Brasileiro, 1990.

SILVA, Juremir Machado. 0 pensamento do fim do século. Porto Alegre: L\&PM, 1993. 